\title{
Analisis Curah Hujan Serial Terhadap Debit Maksimum di Sub DAS Kampili, DAS Jeneberang, Sulawesi Selatan
}

\author{
Nadia Salsabila ${ }^{*}$, Lily Montarcih Limantara ${ }^{1}$, Jadfan Sidqi \\ Fidari $^{1}$ \\ ${ }^{1}$ Jurusan Teknik Pengairan, Fakultas Teknik, Universitas Brawijaya, \\ Jalan MT. Haryono No. 167, Malang, 65145, INDONESIA \\ *Korespondensi Email: nadiasalsabila210@gmail.com
}

\begin{abstract}
The serial rainfall that occurs in South Sulawesi with heavy rainfall to very heavy rainfall has the potential to cause hydrometeorological disasters such as inundation, floods, landslides, and flash floods. Flood disasters due to high rainfall occur in several areas including in the Kampili Sub-watershed, Gowa Regency. This study identifies the equivalence of serial rainfall accumulation to the design flood discharge to determine the state of serial rainfall that causes flood events. The method used is the Collins Method of Observed Unit Hydrograph (OUH) and the Nakayasu Synthesis Unit Hydrograph (SUH) which analyze the equivalence of serial rainfall accumulation with design flood discharge relatively. The relative error (\%) in the comparison of Collins OUH and Nakayasu SUH for peak time (Tp) is $5.35 \%$ and peak discharge (Qp) is $15.36 \%$. In this case study, the 2-year design rainfall of $98.299 \mathrm{~mm}$ is equivalent to the accumulated serial rainfall of $62 \mathrm{~mm}$. As for $\mathrm{Q}_{1.1 \mathrm{yr}}$ of $49.913 \mathrm{~m}^{3} / \mathrm{s}$ caused by serial rainfall with moderate rainfall in the flood event on $7^{\text {th }}$ October 2012, heavy rainfall in the flood events on $9^{\text {th }}$ March $2011,12^{\text {th }}$ February $2015,3^{\text {rd }}$ February 2017 , and very heavy rainfall in the flood event on $20^{\text {th }}$ April 2013.
\end{abstract}

Keywords: Maximum Discharge, Observed Unit Hydrograph, Serial Rainfall, SUH Nakayasu

Abstrak: Curah hujan serial yang terjadi di Sulawesi Selatan dengan keadaan curah hujan lebat hingga curah hujan sangat lebat berpotensi menimbulkan bencana hidrometerologi seperti genangan, banjir, tanah longsor, dan banjir bandang. Bencana banjir akibat curah hujan tinggi ini terjadi di beberapa daerah termasuk di Sub DAS Kampili, Kabupaten Gowa. Penelitian ini mengidentifikasi kesetaraan akumulasi curah hujan serial terhadap debit banjir rancangan untuk mengetahui keadaan curah hujan serial penyebab kejadian banjir. Metode yang digunakan adalah 
Hidrograf Satuan Observasi (HSO) Metode Collins dan Hidrograf Satuan Sintesis (HSS) Nakayasu yang kemudian akan dianalisa kesetaraan akumulasi curah hujan serial dengan debit banjir rancangan secara relatif. Hasil kesalahan relatif (\%) pada perbandingan HSO Collins dan HSS Nakayasu untuk waktu puncak (Tp) sebesar 5,35\% dan debit puncak (Qp) sebesar 15,36\%. Pada studi kasus ini, curah hujan rancangan kala ulang 2 tahun sebesar 98,299 $\mathrm{mm}$ setara dengan akumulasi curah hujan serial sebesar $62 \mathrm{~mm}$. Sedangkan untuk $\mathrm{Q}_{1,1 \text { th }}$ sebesar 49,913 $\mathrm{m}^{3} / \mathrm{dt}$ disebabkan oleh curah hujan serial dengan keadaan curah hujan sedang pada kejadian banjir tanggal 7 Oktober 2012, curah hujan lebat pada kejadian banjir tanggal 9 Maret 2011, 12 Februari 2015, 3 Februari 2017, serta curah hujan sangat lebat pada kejadian banjir tanggal 20 April 2013.

Kata kunci: Curah Hujan Serial, Debit Maksimum, Hidrograf Satuan Obeservasi, HSS Nakayasu

\section{Pendahuluan}

Kondisi Daerah Aliran Sungai (DAS) Jeneberang termasuk ke dalam kondisi yang kritis dikarenakan terjadi pendangkalan pada Sungai Jeneberang. Menurut rekaman Badan Nasional Penanggulangan Bencana (BNPB), cuaca ekstrem merupakan penyebab banjir yang terjadi di 7 kecamatan yaitu Parangloe, Pattalassang, Manuju, Pallangga, Somba Opu, Bontomarannu, dan Tompobulu di Kabupaten Gowa. Intensitas curah hujan yang tinggi mengakibatkan terjadinya peningkatan volume air sungai di kawasan sekitar. Peningkatan volume air sungai dan kondisi DAS yang kritis menjadi penyebab terjadinya banjir. Selain itu, jika dilihat berdasarkan letak wilayah administrasi, Sub DAS Kampili memiliki daerah dengan topografi bervariasi sehingga daerah tangkapan hujan mempunyai curah hujan yang cukup tinggi.

Berdasarkan Badan Meteorologi Klimatologi dan Geofisika (BMKG), curah hujan yang tercatat di Sulawesi Selatan termasuk ke dalam kategori hujan sangat lebat dengan intensitas yang mencapai $110 \mathrm{~mm} / \mathrm{hari}$ dan bahkan kategori hujan ekstrem dengan intensitas yang mencapai $197 \mathrm{~mm} / \mathrm{hari}$. Curah hujan serial yang terjadi di Sulawesi Selatan dengan kategori hujan lebat hingga hujan sangat lebat berlangsung dengan durasi sekitar 4 jam dan berlanjut hingga keesokan harinya [1] (diakses Mei 24, 2021). Potensi terjadinya bencana hidrometeorologi bak genangan, luapan air/banjir, banjir bandang, tanah longsor, jalan culas dan pohon tumbang, dipicu oleh hujan lebat yang bersamaan dengan kilat/petir serta angin.

Besarnya debit banjir dapat diestimasi dengan memperkirakan besarnya limpasan yang terjadi pada suatu DAS. Estimasi tersebut dilakukan dengan pendekatan analisa hidrologi [2]. Cara untuk mendapatkan hidrograf satuan observasi, diperlukan rekaman data historis AWLR, data debit terukur, dan data historis hujan harian serta jam-jaman dari ARR [3]. Nilai debit banjir (design flood) ditentukan oleh data debit yang merupakan data utama yang digunakan. Data debit didapatkan dari hasil rekaman naik dan turunnya tinggi muka air sungai pada pos AWLR [4]. Jika tidak terdapat AWLR, analisa data curah hujan pada suatu DAS dapat digunakan untuk memperkirakan debit banjir rancangan dikarenakan data hujan tersebut merupakan masukan yang penting [5]. 
Kejadian banjir yang terjadi disebabkan oleh indikasi potensi curah hujan tinggi dengan rentang waktu bulanan dan potensi hujan lebat dalam kurun waktu harian. Penelitian ini bertujuan untuk mengetahui perbandingan antara akumulasi curah hujan serial dengan curah hujan rancangan, perbandingan puncak pada debit maksimum antara curah hujan serial dan curah hujan rancangan dan mengetahui kesetaraan debit banjir rancangan dengan curah hujan serial di Sub DAS Kampili.

\section{Bahan dan Metode}

\subsection{Bahan}

\section{A. Lokasi Penelitian}

Penelitian dilaksanakan di Sub DAS Kampili yang termasuk pada daerah cakupan Balai Besar Wilayah Jeneberang, Sulawesi Selatan. Luas Sub DAS Kampili adalah 630 $\mathrm{km}^{2}$ dengan panjang sungai utama 55 kilometer. Letak AWLR dan stasiun hujan di Sub DAS Kampili berada pada $5^{\circ} 16^{\prime}$ '51,37' LS dan $119^{\circ} 30^{\prime}$ 50,70” BT. Lokasi penelitian yang ditampilkan pada Gambar 1 diperoleh dari hasil digitasi menggunakan software sistem informasi geografis sehingga dapat diketahui batas DAS, luas DAS, dan panjang sungai utama.

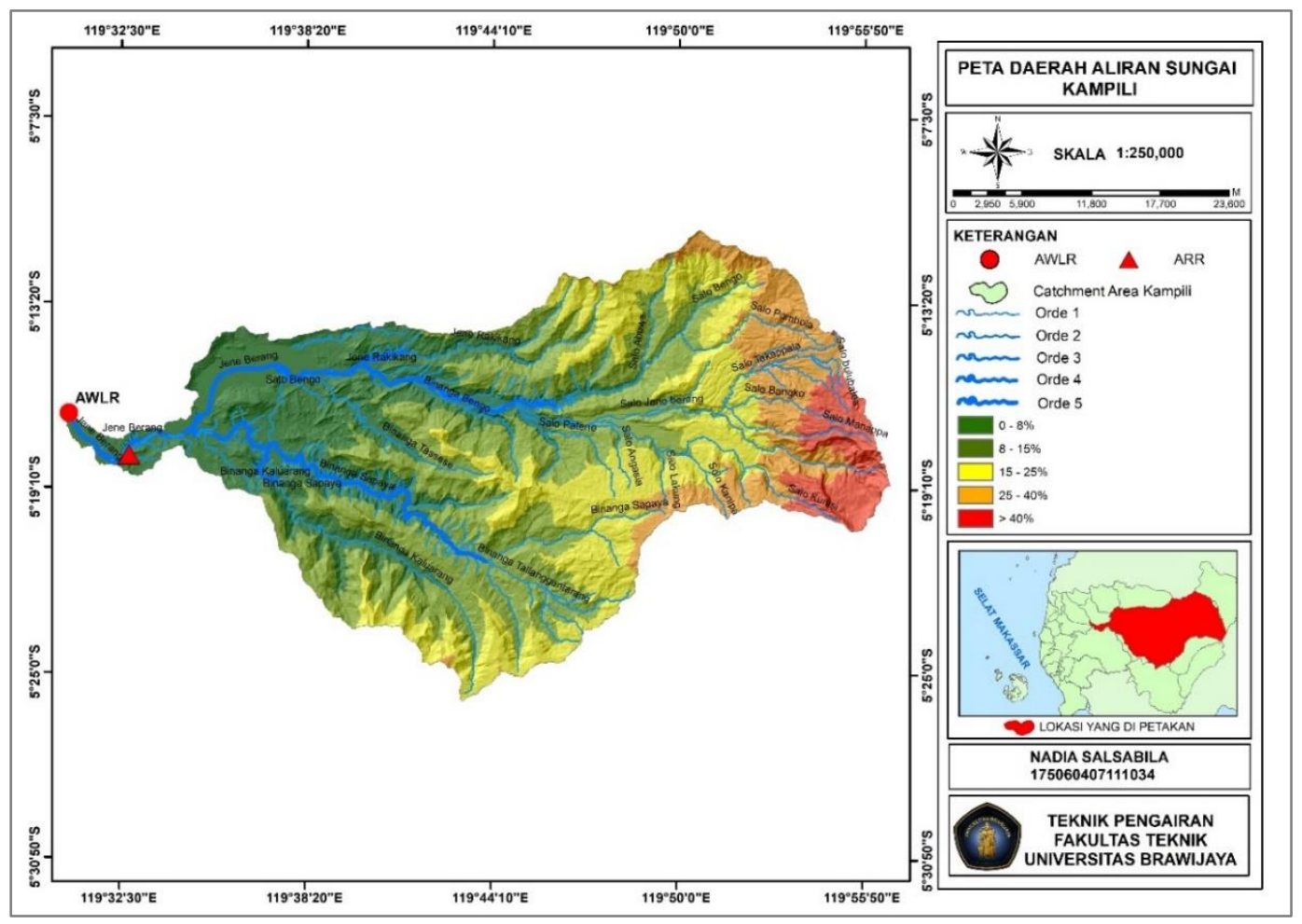

\section{Gambar 1: Peta sub-DAS Kampili}

Kondisi topografi pada Kabupaten Gowa, Sulawesi Selatan didominasi oleh dataran tinggi perbukitan sebanyak 72,26\% pada wilayah Kecamatan Tinggi Moncong, Kecamatan Parangloe, Kecamatan Bontolempangan, Kecamatan Tompobulu, dan Kecamatan Bongayya, sedangkan $27,74 \%$ sisanya merupakan dataran rendah. Sedangkan kondisi 
klimatologi untuk suhu dan curah hujan pada DAS Kampili bervariasi namun tidak terlalu mencolok perbedaannya. Rerata curah hujan berkisar antara $\pm 207,57 \mathrm{~mm}$, sedangkan rerata suhu berkitar antara $\pm 28^{\circ} \mathrm{C}$ [6]. Pada Bulan Oktober suhu dapat mencapai nilai tertinggi yaitu $27,4^{\circ} \mathrm{C}$ dan pada Bulan Desember, Januari, serta Februari, suhu mencapai nilai terendahnya yaitu $25,9^{\circ} \mathrm{C}$. Sedangkan untuk curah hujan tertinggi dapat mencapai nilai 670 mm pada Bulan Januari dan curah hujan terendah sebesar 35,3 mm pada Bulan Agustus [7].

\section{B. Data Penelitian}

Data yang dipakai untuk menunjang ketelitian dan tingkat akurasi dari analisa yang dilakukan adalah data sekunder. Data ini didapatkan dari berbagai instansi terkait yaitu BBWS Pompengan Jeneberang. Data yang digunakan adalah sebagai berikut.

1. Pasangan rekaman data hujan jam - jaman dari alat Automatic Rainfall Recorder (ARR) dan data aliran dari alat Automatic Water Level Recorder (AWLR) selama 10 tahun mulai dari tahun 2010 - 2019 yang akan dianalisa untuk mendapatkan 10 kejadian banjir menggunakan Software Microsoft Excel. Data tersebut juga dipakai dalam perhitungan debit banjir rancangan pada HSS Nakayasu dan perhitungan HSO Metode Collins.

2. Data Peta Rupa Bumi dengan skala 1:50.000 dan Peta Sub Daerah Aliran Sungai Kampili untuk analisa karakteristik Sub DAS Kampili dengan menggunakan Software Sistem Informasi Geografis (SIG).

\subsection{Metode}

Penelitian diawali dengan melakukan studi literatur pendukung dengan cara menelaah dan membandingkan metode-metode penunjang penelitian yang digunakan sebagai referensi. Data yang perlu dikumpulkan guna menunjang penelitian adalah data curah hujan serial yang terekam oleh ARR pada Sta. Kampili, data debit yang terekam oleh AWLR, dan data karakteristik DAS. Sebelum dilakukan analisa, perlu dilakukan uji kualitas data terhadap data curah hujan dan data debit. Uji kualitas data merupakan uji statistik yang meliputi: uji konsistensi, uji stasioner (meliputi uji $\mathrm{F}$ dan uji t), uji persistensi, serta uji outliers data. Uji tersebut diperlukan agar dapat mengetahui apakah data layak untuk dianalisa. Selanjutnya dilakukan analisa pasangan data curah hujan dengan data debit yang sesuai serta pemilihan hidrograf yang mempunyai satu waktu puncak (single peak) guna mempermudah analisa yang diperoleh dari rekaman data AWLR, kemudian akan dianalisa untuk mendapatkan hidrograf satuan observasi menggunakan Metode Collins.

Selain itu, data curah hujan harian maksimum tahunan digunakan untuk perhitungan curah hujan rancangan dengan berbagai kala ulang yang selanjutnya akan dipakai dalam analisa debit banjir rancangan dengan pendekatan HSS Nakayasu. Hujan jam-jaman yang digunakan akan dihitung menggunakan Metode Mononobe dengan durasi 6 jam dan hujan rancangan menggunakan distribusi Log Pearson III. Setelah didapatkan debit banjir rancangan dengan berbagai kala ulang, dapat dilakukan analisa kesetaraan curah hujan serial terhadap debit banjir rancangan. Kesetaraan ini dilakukan secara relatif dengan membandingkan klasifikasi besaran curah hujan serial yang menyebabkan debit banjir rancangan dengan kala ulang tertentu. Klasifikasi tersebut memakai acuan keadaan curah hujan dan intensitas curah hujan [8]. Penelitian ini memakai alat bantu aplikasi Microsoft 
Excel, sedangkan untuk analisa karakteristik DAS dibantu menggunakan aplikasi sistem informasi geografis. Analisa karakteristik DAS dilakukan untuk mengetahui batas DAS, luas DAS, panjang sungai utama, dan koefisien pengaliran (C) pada sub-DAS Kampili. Nilai koefisien pengaliran didapatkan dari analisa peta tata guna lahan dengan menggunakan rumus $\mathrm{C}$ gabungan.

\section{Hasil dan Pembahasan}

\subsection{Analisa Karakteristik Sub DAS Kampili}

Peta sub-DAS Kampili diperlukan agar dapat memperoleh karakteristik DAS seperti luas dan panjang sungai utama, serta untuk mengetahui batas sub-DAS Kampili sehingga peneliti dapat memberikan batasan dalam perhitungan pada penelitian. Selain itu, peta tata guna lahan juga diperlukan untuk mendapatkan nilai koefisien pengaliran (C). Nilai $\mathrm{C}$ yang digunakan adalah nilai $\mathrm{C}$ gabungan dikarenakan penggunaan lahan yang berbeda pada DAS [9]. Tabel hasil analisa karakteristik sub-DAS Kampili ditabelkan pada Tabel 1.

Tabel 1: Rekapitulasi karakteristik sub-DAS Kampili

\begin{tabular}{ccc}
\hline No & Parameter Fisik & Hasil \\
\hline \hline 1 & Luas DAS $\left(\mathrm{km}^{2}\right)$ & 629,703 \\
2 & Panjang Sungai Utama $(\mathrm{km})$ & 58,610 \\
3 & Koefisien Pengaliran $(\mathrm{C})$ & 0,226 \\
\hline
\end{tabular}

\subsection{Analisa Kejadian Banjir}

Kejadian banjir didapatkan dari data setiap tahun yang tersedia dan mempunyai hidrograf berpuncak tunggal (single peak) dengan durasi singkat [10]. Kejadian banjir ini digunakan untuk perhitungan hidrograf satuan observasi menggunakan Metode Collins yang akan dianalisa dengan curah hujan efektif yang terdistribusi secara keseluruhan di sub-DAS Kampili dan debit puncak yang relatif besar. Pada sub-DAS Kampili akan dicari 10 (sepuluh) data single peak dari 10 tahun data yang tersedia. Data kejadian banjir subDAS Kampili sebagaimana tertulis pada Tabel 2.

Tabel 2: Kejadian banjir sub-DAS Kampili

\begin{tabular}{cccc}
\hline $\begin{array}{c}\text { Kejadian } \\
\text { Banjir }\end{array}$ & Tanggal & $\begin{array}{c}\text { Curah Hujan Maksimum } \\
\text { Kejadian Banjir } \\
(\mathrm{mm})\end{array}$ & $\begin{array}{c}\text { Debit Maksimum } \\
\text { Kejadian Banjir } \\
\left(\mathrm{m}^{3} / \mathrm{dt}\right)\end{array}$ \\
\hline \hline 1 & 3 Februari 2010 & 10 & 30,63 \\
2 & 9 Maret 2011 & 20 & 47,36 \\
3 & 7 Oktober 2012 & 7 & 47,36 \\
4 & 20 April 2013 & 44 & 49,20 \\
5 & 1 Februari 2014 & 11 & 68,78 \\
6 & 12 Februari 2015 & 15 & 49,20 \\
7 & 13 Desember 2016 & 12 & 63,43 \\
8 & 3 Februari 2017 & 12 & 48,87 \\
9 & 15 Januari 2018 & 11 & 59,41 \\
10 & 22 Januari 2019 & 32 & 51,55 \\
\hline
\end{tabular}




\subsection{Analisa Curah Hujan Harian Maksimum Tahunan}

Hujan rancangan diperlukan pada perhitungan debit banjir rancangan yang nilainya didapatkan dari analisa curah hujan harian maksimum tahunan. Panjang data yang tersedia untuk stasiun hujan sub-DAS Kampili adalah 10 tahun yang diawali pada tahun 2010 hingga tahun 2019. Data curah hujan harian maksimum tahunan sub-DAS Kampili ditabelkan pada Tabel 3.

Tabel 3: Curah hujan harian maksimum sub-DAS Kampili

\begin{tabular}{ccc}
\hline No & Tahun & $\begin{array}{c}\text { Curah Hujan Harian Maksimum } \\
(\mathrm{mm})\end{array}$ \\
\hline \hline 1 & 2010 & 117 \\
2 & 2011 & 115 \\
3 & 2012 & 112 \\
4 & 2013 & 254 \\
5 & 2014 & 170 \\
6 & 2015 & 48 \\
7 & 2016 & 31 \\
8 & 2017 & 59 \\
9 & 2018 & 187 \\
10 & 2019 & 60 \\
\hline
\end{tabular}

\subsection{Analisa Kualitas Data}

Data yang digunakan akan mempengaruhi keakuratan analisis kesetaraan curah hujan dan debit banjir rancangan, sehingga perlu dilakukan analisa kualitas data secara statistika sebelum dianalisa. Analisa kualitas data yang dilakukan adalah uji konsistensi, uji stasioner, uji persistensi dan uji outliers. Hasil pengujian yang baik menunjukkan bahwa data layak untuk dianalisa lanjutan.

\section{A. Uji Konsistensi}

Untuk melihat kepanggahan dalam suatu seri data yang diperoleh maka diperlukan uji kepanggahan (konsistensi) data digunakan. Metode yang dipakai dalam pengujian ini adalah metode RAPS (Rescaled Adjusted Partial Sums) dikarenakan jumlah stasiun hujan yang digunakan hanya ada 1 stasiun hujan [11]. Uji ini membandingkan hasil perhitungan nilai statistik $\mathrm{Q}$ dan $\mathrm{R}$ dengan nilai kritisnya. Apabila nilai kritis lebih besar dibandingkan dengan nilai hitung, maka data diterima dan sebaliknya. Hasil uji konsistensi data ditabelkan pada Tabel 4 dan Tabel 5.

Tabel 4: Uji konsistensi data kejadian banjir

\begin{tabular}{llcll}
\hline Jenis Data & Nilai Hitung & $\begin{array}{c}\text { Nilai Kritis } \\
(\alpha=5 \%)\end{array}$ & Metode & Keterangan \\
\hline \hline \multirow{2}{*}{ Data Hujan } & $\mathrm{Q} /\left(\mathrm{n}^{0,5}\right)=0,76$ & & RAPS & Konsisten \\
& $\mathrm{R} /\left(\mathrm{n}^{0,5}\right)=1,05$ & $\mathrm{Q} /\left(\mathrm{n}^{0,5}\right)=1,14$ & & \\
\multirow{2}{*}{ Data Debit } & $\mathrm{Q} /\left(\mathrm{n}^{0,5}\right)=0,67$ & $\mathrm{R} /\left(\mathrm{n}^{0,5}\right)=1,28$ & RAPS & Konsisten \\
\hline
\end{tabular}


Tabel 5: Uji konsistensi data curah hujan harian maksimum

\begin{tabular}{ccccc}
\hline $\begin{array}{c}\text { Jenis } \\
\text { Data }\end{array}$ & Nilai Hitung & $\begin{array}{c}\text { Nilai Kritis } \\
(\alpha=5 \%)\end{array}$ & Metode & Keterangan \\
\hline \hline Data & $\mathrm{Q} /\left(\mathrm{n}^{0,5}\right)=0,65$ & $\begin{array}{l}\mathrm{Q} /\left(\mathrm{n}^{0,5}\right)=1,14 \\
\mathrm{R} /\left(\mathrm{n}^{0,5}\right)=1,28\end{array}$ & RAPS & Konsisten \\
Hujan & $\mathrm{R} /\left(\mathrm{n}^{0,5}\right)=1,05$ & & & \\
\hline
\end{tabular}

B. Uji Stasioner

Stabilitas nilai varian dan rerata dari suatu deret waktu yang dimana pada studi ini adalah data debit dan data hujan dapat dilihat dengan uji stasioner. Pada penelitian ini akan dilakuka uji stasioner dengan uji kestabilan varian (Uji F) dan uji kestabilan rerata (Uji t). Jika nilai terhitung lebih besar dibandingkan nilai kritis, maka data yang diuji tidak berasal dari populasi yang sama atau tidak stasioner pada taraf signifikansi tertentu [12]. Nilai varian tidak stabil dan tidak homogen apabila hasil pengujian menunjukkan hipotesis nol ditolak [13]. Hasil uji stasioner ditabelkan pada Tabel 6 dan Tabel 7.

Tabel 6: Uji stasioner data kejadian banjir

\begin{tabular}{lcccc}
\hline Jenis Data & Nilai Hitung & $\begin{array}{c}\text { Nilai Kritis } \\
(\alpha=5 \%)\end{array}$ & Metode & Keterangan \\
\hline \hline \multirow{2}{*}{ Data Hujan } & 2,920 & 6,390 & Uji F & Varian Sama \\
& 0,230 & 2,306 & Uji t & Rerata Stabil \\
\multirow{2}{*}{ Data Debit } & 4,260 & 6,390 & Uji F & Varian Sama \\
& 0,770 & 2,306 & Uji t & Rerata Stabil \\
\hline
\end{tabular}

Tabel 7: Uji stasioner data curah hujan harian maksimum

\begin{tabular}{lcccc}
\hline Jenis Data & Nilai Hitung & $\begin{array}{c}\text { Nilai Kritis } \\
(\alpha=5 \%)\end{array}$ & Metode & Keterangan \\
\hline \hline \multirow{2}{*}{ Data Hujan } & 0,950 & 6,390 & Uji F & Varian Sama \\
& 1,750 & 2,306 & Uji t & Rerata Stabil \\
\hline
\end{tabular}

\section{Uji Persistensi}

Uji persistensi pada penelitian ini digunakan sebagai persyaratan dalam analisis frekuensi dengan menguji ada atau tidaknya ketergantungan dari setiap data. Jika pada uji ini tidak ditemukan ketergantungan dari setiap nilai, maka data tersebut dapat digunakan dalam analisis frekuensi. Besarnya koefisien korelasi perlu diperhitungkan [13]. Hasil uji persistensi ditabelkan pada Tabel 8.

Tabel 8: Uji persistensi data curah hujan harian maksimum

\begin{tabular}{ccccc}
\hline Jenis Data & Nilai Hitung & $\begin{array}{c}\text { Nilai Kritis } \\
(\alpha=5 \%)\end{array}$ & Metode & Keterangan \\
\hline \hline Data Hujan & $-1,333$ & 1,806 & Spearman & Independen \\
\hline
\end{tabular}

D. Uji Outliers

Uji outliers digunakan untuk mengetahui penyimpangan data terhadap trend-nya sehingga data tersebut layak digunakan atau tidak. Data pada penelitian ini menunjukkan 
data debit dan data hujan kejadian banjir maupun hujan harian maksimum tahunan berada dalam batas atas dan batas bawah yang ditentukan, maka data dapat digunakan untuk analisa selanjutnya. Hasil uji outliers ditabelkan pada Tabel 9 dan 10.

Tabel 9: Uji outliers data kejadian banjir

\begin{tabular}{cccc}
\hline Jenis Data & Batas Bawah & Batas Atas & Keterangan \\
\hline \hline Data Hujan & 4,685 & 47,248 & Tidak Menyimpang \\
Data Debit & 28,643 & 77,817 & Tidak Menyimpang \\
\hline
\end{tabular}

Tabel 10: Uji outliers data curah hujan harian maksimum

\begin{tabular}{cccc}
\hline Jenis Data & Batas Bawah & Batas Atas & Keterangan \\
\hline \hline Data Hujan & 24,493 & 375,523 & Tidak Menyimpang \\
\hline
\end{tabular}

\subsection{Analisa Hidrograf Satuan Observasi}

Perhitungan HSO diawali dengan analisa hujan efektif untuk mendapatkan nilai Ut awal. Hujan efektif didapatkan dari selisih total hujan dengan kedalaman limpasan dibagi durasi hujan [14]. Hujan efektif juga dihitung menggunakan phi indeks. Selanjutnya dilakukan perhitungan nilai Ut-2 serta nilai t/Tp dan nilai Q/Qp pada setiap HSO pada 10 kejadian banjir kemudian dihitung nilai reratanya. Perhitungan dilakukan dengan cobacoba dengan kontrol nilai faktor perubahan $\mathrm{q}=1$. Hal ini bertujuan untuk memperoleh hidrograf satuan yang mewakili sub-DAS Kampili dari 10 hidrograf kejadian banjir. Data kejadian banjir yang digunakan dimulai pada tahun 2010 hingga 2019. Rekapitulasi hasil perhitungan Tp dan Qp ditabelkan pada Tabel 11.

Tabel 11: Rekapitulasi Tp dan Qp pada HSO Collins

\begin{tabular}{|c|c|c|c|}
\hline \multirow[b]{2}{*}{$\mathrm{HSO}$} & \multirow[b]{2}{*}{ Tanggal } & \multicolumn{2}{|c|}{ Rekapitulasi HSO Collins } \\
\hline & & $\begin{array}{l}\text { Waktu Puncak } \\
\text { (Tp) (Jam) }\end{array}$ & $\begin{array}{c}\text { Debit Puncak (Qp) } \\
\left(\mathrm{m}^{3} / \mathrm{dt}\right)\end{array}$ \\
\hline HSO-1 & 3 September 2010 & 3 & 4,279 \\
\hline HSO-2 & 9 Maret 2011 & 4 & 5,788 \\
\hline HSO-3 & 7 Oktober 2012 & 5 & 3,610 \\
\hline HSO-4 & 20 April 2013 & 3 & 3,573 \\
\hline HSO-5 & 1 Februari 2014 & 4 & 2,393 \\
\hline HSO-6 & 12 Februari 2015 & 5 & 2,800 \\
\hline HSO-7 & 13 Desember 2016 & 5 & 3,957 \\
\hline HSO-8 & 3 Februari 2017 & 2 & 12,668 \\
\hline HSO-9 & 15 Januari 2018 & 3 & 3,926 \\
\hline HSO-10 & 22 Januari 2019 & 6 & 2,382 \\
\hline & Rerata & 4,00 & 4,538 \\
\hline
\end{tabular}

Untuk mendapatkan hidrograf satuan observasi yang mewakili DAS Kampili selama 10 tahun data kejadian banjir (2010 - 2019), maka perlu dilakukan perhitungan nilai rerata dengan mencari nilai Q dan $\mathrm{T}$ dari Q/Qp dan T/Tp tiap-tiap hidrograf. Hidrograf satuan observasi pada sub-DAS Kampili dapat dilihat pada Gambar 2. 


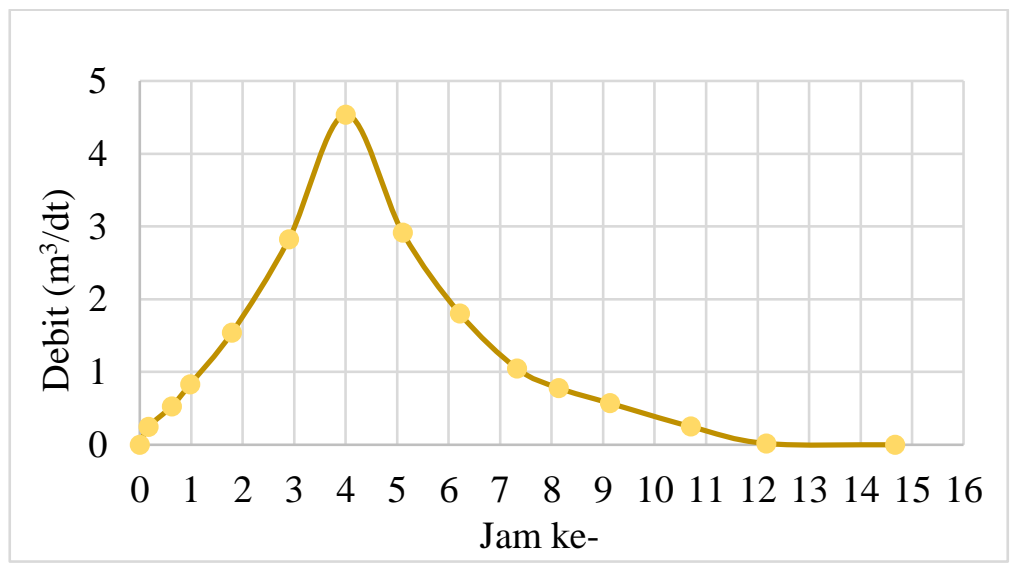

Gambar 2: Hidrograf satuan observasi sub-DAS Kampili

\subsection{Analisa Hidrograf Satuan Sintesis}

Perhitungan HSS didasarkan pada karakteristik fisik DAS yang diawali dengan perhitungan hujan rancangan berbagai kala ulang. Distribusi frekuensi yang dipilih adalah Log Pearson III karena dianggap relatif fleksibel. Rekapitulasi hasil perhitungan curah hujan rancangan ditabelkan pada Tabel 12.

Tabel 12: Rekapitulasi curah hujan rancangan

\begin{tabular}{ccc}
\hline No & $\begin{array}{c}\text { Tr } \\
\text { (tahun) }\end{array}$ & $\begin{array}{c}\text { Curah Hujan Rancangan } \\
(\mathrm{mm})\end{array}$ \\
\hline \hline 1 & 1,11 & 75,589 \\
2 & 1,25 & 82,466 \\
3 & 2 & 98,299 \\
4 & 5 & 169,077 \\
5 & 10 & 221,054 \\
6 & 25 & 291,011 \\
7 & 50 & 345,543 \\
8 & 100 & 401,478 \\
9 & 200 & 459,202 \\
10 & 1000 & 599,817 \\
\hline
\end{tabular}

Uji kesesuaian distribusi untuk mengetahui apakah metode analisa frekuensi telah sesuai. Pada penelitian ini, akan dilakukan 2 uji kesesuaian distribusi yaitu Uji Chi-Square (penyimpangan data ke arah vertikal) dan Uji Smirnov-Kolmogorov (penyimpangan data ke arah horizontal). Hasil uji kesesuaian distribusi ditabelkan pada Tabel 13.

Tabel 13: Uji kesesuaian distribusi

\begin{tabular}{|c|c|c|c|c|}
\hline Jenis Uji & $\begin{array}{c}\text { Nilai } \\
\text { Hitung }\end{array}$ & $\begin{array}{l}\text { Nilai Kritis } \\
(\alpha=5 \%)\end{array}$ & $\begin{array}{c}\text { Nilai Kritis } \\
(\alpha=1 \%)\end{array}$ & Keterangan \\
\hline Chi-Square $\left(\mathrm{X}^{2}\right)$ & 3,600 & 3,941 & 6,630 & Diterima \\
\hline Smirnov Kolmogorov & 0,119 & 0,409 & 0,486 & Diterima \\
\hline
\end{tabular}

Hidrograf satuan sintesis digunakan untuk mengestimasi debit banjir rancangan dengan pendekatan dari ordinat hidrograf satuan sintesis yang didapatkan dari perhitungan 
beberapa parameter. Parameter yang digunakan adalah luas DAS (A) $=629,703 \mathrm{~km}^{2}$, panjang sungai utama $(\mathrm{L})=58,61 \mathrm{~km}$, koefisien pengaliran $(C)=0,23$, alfa $(\alpha)=3$ didapatkan dari kontrol HSO Collins, dan hujan satuan $(\mathrm{Ro})=1 \mathrm{~mm}$. Hidrograf satuan sintesis untuk sub-DAS Kampili dapat dilihat pada Gambar 3.

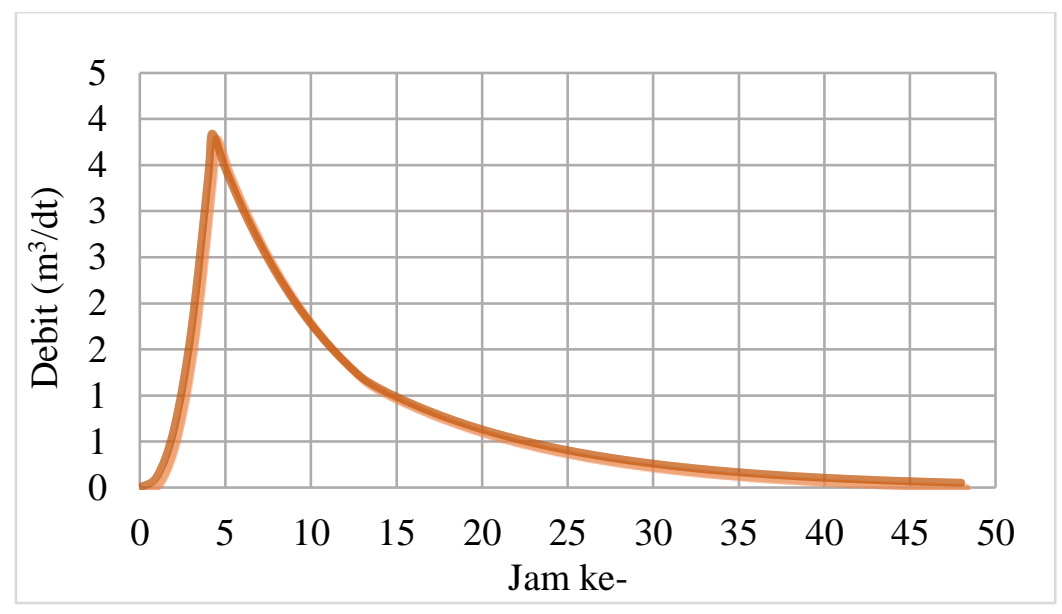

Gambar 3: Hidrograf satuan sintesis sub-DAS Kampili

\subsection{Debit Banjir Rancangan}

Debit banjir rancangan dapat dianalisa setelah mendapatkan hidrograf satuan sintesis yang kemudian akan dihitung dari nilai hujan jam-jaman sesuai dengan kala ulangnya yang sudah dianalisa dengan Metode Mononobe dan durasi hujan yang digunakan selama 6 jam. Pada studi ini akan menganalisa besaran debit banjir rancangan kala ulang 1,11 tahun, 1,25 tahun, 2 tahun, 5 tahun, 10 tahun, 25 tahun, 50 tahun, 100 tahun, 200 tahun, dan 1000 tahun. Rekapitulasi hasil perhitungan debit banjir rancangan di sub-DAS Kampili ditabelkan pada Tabel 14.

Tabel 14: Rekapitulasi debit banjir rancangan

\begin{tabular}{ccc}
\hline No & $\begin{array}{c}\text { Tr } \\
\text { (tahun) }\end{array}$ & $\begin{array}{c}\text { Debit Banjir Rancangan } \\
\left(\mathrm{m}^{3} / \mathrm{dt}\right)\end{array}$ \\
\hline \hline 1 & 1,11 & 49,913 \\
2 & 1,25 & 54,160 \\
3 & 2 & 63,940 \\
4 & 5 & 107,658 \\
5 & 10 & 139,764 \\
6 & 25 & 182,975 \\
7 & 50 & 216,659 \\
8 & 100 & 251,209 \\
9 & 200 & 286,865 \\
10 & 1000 & 373,720 \\
\hline
\end{tabular}

3.8 Perbandingan Waktu Hidrograf Satuan Observasi dan Hidrograf Satuan Sintetis

Perbandingan nilai waktu puncak (Tp) dan debit puncak (Qp) pada HSO Collins dan HSS Nakayasu dapat dilihat pada Gambar 4 dan disimpulkan bahwa keduanya memiliki nilai yang berbeda. 


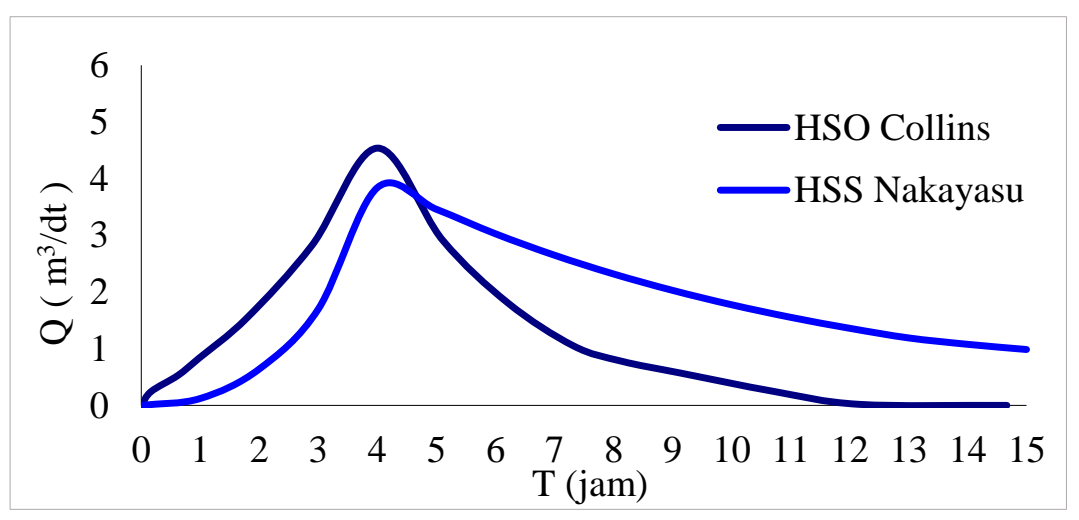

Gambar 4: Perbandingan hidrograf satuan observasi Collins dan hidrograf satuan sintesis Nakayasu

Untuk melihat presentase perbedaan nilai yang terjadi, maka akan dilakukan perhitungan kesalahan relatif (KR). Hasil perhitungan kesalahan relatif pada waktu puncak (Tp) dan debit puncak (Qp) digunakan sebagai kontrol hidrograf. Hasil perhitungan nilai kesalahan relatif ditabelkan pada Tabel 15.

Tabel 15: Rekapitulasi nilai kesalahan relatif

\begin{tabular}{cccccc}
\hline & $\begin{array}{c}\text { Waktu Puncak (Tp) } \\
\text { (jam) }\end{array}$ & KR $\%)$ & Collins & $\begin{array}{c}\text { Debit Puncak (Qp) } \\
\left(\mathrm{m}^{3} / \mathrm{dt}\right)\end{array}$ \\
Collins & Nakayasu & Kakasu & KR (\%) \\
\hline \hline 4,000 & 4,214 & 5,350 & 4,538 & 3,841 & 15,359 \\
\hline
\end{tabular}

\subsection{Analisa Kesetaraan Curah Hujan Terhadap Debit Banjir Rancangan}

Kesetaraan curah hujan serial terhadap debit banjir rancangan didapatkan dengan mencari klasifikasi besaran curah hujan yang mengakibatkan terjadinya debit banjir tersebut. Klasifikasi tersebut memakai acuan keadaan curah hujan dan intensitas curah hujan selama kejadian banjir berlangsung.

Tabel 16: Keadaan curah hujan serial dan debit eksisting 1 Februari 2014

\begin{tabular}{ccccccc}
\hline $\begin{array}{c}\text { Tanggal } \\
\text { Kejadian } \\
\text { Banjir }\end{array}$ & $\begin{array}{c}\text { Jam } \\
\text { ke- }\end{array}$ & $\begin{array}{c}\text { Debit } \\
\text { AWLR } \\
(\text { Eksisting }) \\
\left(\mathrm{m}^{3} / \mathrm{dt}\right)\end{array}$ & $\begin{array}{c}\text { Curah } \\
\text { Hujan } \\
\text { ARR } \\
(\mathrm{mm})\end{array}$ & Keadaan Curah Hujan & $\begin{array}{c}\text { Curah } \\
\text { Hujan } \\
\text { Total } \\
(\mathrm{mm})\end{array}$ & $\begin{array}{c}\text { Keadaan } \\
\text { Curah Hujan }\end{array}$ \\
\hline \hline & 0 & 48,70 & 5 & Hujan Ringan & & \\
& 1 & 56,07 & 11 & Hujan Lebat & & \\
& 2 & 59,75 & 10 & Hujan Sedang & & \\
& 3 & 65,44 & 5 & Hujan Ringan & & \\
& 4 & 68,78 & 3 & Hujan Ringan & & \\
$1 / 2 / 2014$ & 5 & 68,28 & 1 & Hujan Ringan & 62 & \\
& 6 & 65,61 & 1 & Hujan Ringan & & \\
& 7 & 62,43 & 5 & Hujan Ringan & & \\
& 8 & 59,91 & 9 & Hujan Sedang & & \\
& 9 & 58,07 & 7 & Hujan Sedang & & \\
& 10 & 56,90 & 5 & Hujan Ringan & & \\
& 11 & 55,73 & 0 & Hujan Sangat Ringan & & \\
\hline
\end{tabular}


Keadaan curah hujan serial dan debit eksisting dianalisa untuk setiap kejadian banjirnya. Pada Tabel 16, dapat dilihat analisa keadaan curah hujan serial dan debit eksisting pada kejadian banjir tanggal 1 Februari 2014. Kejadian banjir lainnya dianalisa dengan cara yang sama. Setelah dilakukan analisa terhadap keadaan curah hujan serial dan debit eksisting, maka akan dilakukan kesetaraan curah hujan setial terhadap debit banjir rancangan.

Tabel 17: Kesetaraan curah hujan serial dan debit banjir rancangan

\begin{tabular}{ccccc}
\hline $\begin{array}{c}\text { Kejadian } \\
\text { Banjir }\end{array}$ & $\begin{array}{c}\text { Debit Banjir } \\
\text { Eksisting } \\
\text { Maksimum } \\
\left(\mathrm{m}^{3} / \mathrm{dt}\right)\end{array}$ & $\begin{array}{c}\text { Kala } \\
\text { Ulang } \\
\text { (tahun) }\end{array}$ & $\begin{array}{c}\text { Curah } \\
\text { Hujan } \\
\text { Total } \\
(\mathrm{mm})\end{array}$ & Keadaan Curah Hujan \\
\hline $3 / 2 / 2010$ & 30,63 & $<1,110$ & 26 & Hujan Sedang \\
$9 / 3 / 2011$ & 47,36 & 1,10 & 74 & Hujan Lebat \\
$7 / 10 / 2012$ & 47,36 & 1,110 & 26 & Hujan Sedang \\
$20 / 4 / 2013$ & 49,20 & 1,110 & 106 & Hujan Sangat Lebat \\
$1 / 2 / 2014$ & 68,78 & 2,000 & 62 & Hujan Lebat \\
$12 / 2 / 2015$ & 49,20 & 1,110 & 48 & Hujan Sedang \\
$13 / 12 / 2016$ & 63,43 & 2,000 & 30 & Hujan Sedang \\
$3 / 2 / 2017$ & 48,87 & 1,110 & 24 & Hujan Sedang \\
$15 / 1 / 2018$ & 59,41 & 1,250 & 35 & Hujan Sedang \\
$22 / 1 / 2019$ & 51,55 & 1,250 & 65 & Hujan Lebat \\
\hline
\end{tabular}

Dapat dilihat pada Tabel 17 bahwa 5 dari 10 debit banjir yang terjadi kejadian banjir memiliki nilai yang mendekati nilai debit banjir rancangan kala ulang 1,11 tahun dan sisanya memiliki nilai yang mendekati nilai debit banjir rancangan kala ulang 1,25 tahun dan 2 tahun sehingga dapat dikatakan debit banjir pada DAS Kampili terjadi hampir setiap tahunnya. Untuk debit banjir kala ulang 2 tahun sebesar $63,940 \mathrm{~m}^{3} / \mathrm{dt}$ setara dengan debit eksisting pada kejadian banjir tanggal 1 Februari 2014 pada jam ke-4 sebesar 68,78 m²/dt yang diakibatkan curah hujan sebesar $11 \mathrm{~mm}$ (hujan lebat) yang terjadi pada jam sebelumnya.

Debit banjir rancangan kala ulang 1,11 tahun disebabkan oleh curah hujan sedang hingga sangat lebat, sedangkan debit banjir rancangan kala ulang 1,25 tahun dan 2 tahun disebabkan oleh curah hujan sedang hingga lebat.

\section{Kesimpulan}

Berdasarkan hasil analisa didapatkan bahwa hujan rancangan kala ulang 2 tahun sebesar 98,299 mm setara dengan curah hujan serial yang tercatat di lapangan dengan jumlah sebesar $62 \mathrm{~mm}$. Pada perhitungan hujan rancangan digunakan pendekatan Log Pearson Tipe III sedangkan nilai curah hujan serial didapatkan dari hasil pengukuran curah hujan langsung di lapangan, sehingga menyebabkan terjadinya perbedaan nilai curah hujan rancangan dan curah hujan serial.

HSO Collins dan HSS Nakayasu DAS Kampili memiliki waktu puncak (Tp) dan debit puncak (Qp) yang berbeda. Perbedaan tersebut menunjukkan adanya penyimpangan yang disebabkan oleh perbedaan parameter yang digunakan seperti panjang sungai utama (L), koefisien pengaliran $(\mathrm{C})$, dan nilai alfa $(\alpha)$. Kesalahan relatif $(\mathrm{KR})$ dari waktu puncak HSO 
Collins dan HSS Nakayasu adalah 5,35\%, sedangkan untuk kesalahan relatif dari debit puncak adalah $15,36 \%$. Untuk mengurangi kesalahan relatif sebaiknya panjang data dan jumlah stasiun hujan yang digunakan lebih banyak.

Pada studi ini, sebagian besar kejadian banjir eksisting memiliki nilai yang mendekati nilai $\mathrm{Q}_{1,11 \text { th }}$ atau dapat dikatakan hampir setiap tahun terjadi banjir di DAS Kampili. Nilai $\mathrm{Q}_{1,11 \text { th }}$ sebesar $49,913 \mathrm{~m}^{3} / \mathrm{dt}$ pada jam ke-6 yang setara dengan debit eksisting maksimum sebesar 47,36 m²/dt pada jam ke-4 tanggal 9 Maret 2011 yang diakibatkan oleh curah hujan lebat sebesar $20 \mathrm{~mm}, 47,36 \mathrm{~m}$ /dt pada jam ke-5 tanggal 7 Oktober 2012 yang diakibatkan oleh curah hujan sedang sebesar $7 \mathrm{~mm}, 49,20 \mathrm{~m}$ / dt pada jam ke-3 tanggal 20 April 2013 yang diakibatkan oleh curah hujan sangat lebat sebesar $44 \mathrm{~mm}, 49,20 \mathrm{~m}^{3} / \mathrm{dt}$ pada jam ke-4 tanggal 12 Februari 2015 yang diakibatkan oleh curah hujan lebat sebesar $15 \mathrm{~mm}$, dan $48,87 \mathrm{~m}^{3} / \mathrm{dt}$ pada jam ke-2 tanggal 3 Februari 2017 yang diakibatkan oleh curah hujan lebat sebesar $12 \mathrm{~mm}$. Hujan lebat yang terjadi pada DAS Kampili mengakibatkan kondisi tanah menjadi jenuh dan terjadi debit banjir.

\section{Daftar Pustaka}

[1] Anonim, "Dampak Hujan Lebat Melanda Sulawesi Selatan, Banjir dan Pohon Tumbang di Beberapa Tempat," $B M K G, 2016$. [Online]. Available: https://www.bmkg.go.id/berita/?p=dampak-hujan-lebat-melanda-sulawesi-selatanbanjir-dan-pohon-tumbang-di-beberapa-tempat\&lang=ID\&tag=meteorologi. [Accessed May 24, 2021].

[2] F. A. Rini, L. M. Limantara, dan S. Wahyuni, "Analisis Penentuan Nilai Parameter Alfa Model Hidrograf Satuan Sintesis Nakayasu pada DAS Kampili Provinsi Sulawesi Selatan,” J. Tek. Pengair., vol. 3, no. 2, 2020.

[3] F. J. Fachri, "Analisis Hidrograf Sungai dengan Menggunakan HSS di Daerah Aliran Sungai Jeneberang Kabupaten Gowa,” Universitas Hassanudin, 2017.

[4] Maizir dan V. A. Sorandicha, "Analisis Korelasi Debit Banjir Rencana Berdasarkan Data Hujan dan Data Debit pada Sungai Batang Sikilang D Kabupaten Pasaman," Ensiklopedia J., vol. 3, no. 2, 2021.

[5] A. A. Sahanaya, D. Harisuseno, dan L. M. Limantara, "Pengaruh Panjang Data Terhadap Besaran Debit Banjir Pada Sub Das Brangkal Kabupaten Mojokerto," J. Tek. Pengair., 2014.

[6] Kementrian Lingkungan Hidup dan Kehutanan. "Status Lingkungan Hidup Daerah Kabupaten Gowa Tahun 2009,” 2010.

[7] M. C. Fahmi, "Pengelolaan Daerah Aliran Sungai Jeneberang Kota Makassar Sulawesi Selatan."

[8] S. Sosrodarsono dan K. Takeda, Hidrologi untuk Pengairan. Jakarta: Paradnya Paramita, 2003.

[9] Suripin, Sistem Drainase Perkotaan yang Berkelanjutan. Yogyakarta: Andi Offset, 2004.

[10] L. M. Limantara, Rekayasa Hidrologi, Revisi. Yogyakarta: Penerbit ANDI, 2018. 
[11] S. Harto, Analisis Hidrologi. Jakarta: Gramedia Pustaka Utama, 1993.

[12] I. M. Kamiana, Teknik Perhitungan Rencana Bangunan Air. Yogyakarta: Graha Ilmu, 2011.

[13] Soewarno, Hidrologi Aplikasi Metode Statistik untuk Analisa Data. Bandung: Penerbit Nova, 1995.

[14] B. Triatmodjo, Hidrologi Terapan. Yogyakarta: Beta Offset, 2016. 